Obituary

\title{
CRODOWALDO PAVAN (1919-2009): One of a Kind
}

Crodowaldo Pavan passed away on April $3^{\text {rd }}, 2009$, in the city of São Paulo, Brazil. Born in Campinas, on November 29th, 1919, as the son of Rosária and Henrique Pavan, he was married to the late Maria de Lourdes de Oliveira Pavan and leaves behind three sons, daughters-in-law and grandchildren.

Soon after his birth, his family who manufactured china moved to Mogi das Cruzes, where he lived until the age of 11. That was where he learned to love "the things of Nature", as Professor Antonio Brito da Cunha described it so very accurately (Ciência e Cultura 42:688-696, 1990). He moved to São Paulo to proceed with his studies. After hesitating about which career to pursue, he chose the course of Natural History of the then called Faculdade de Filosofia, Ciências e Letras (School of Philosophy, Sciences and Humanities) at the University of São Paulo (USP). Once graduated, he was invited to work in the Department of General Biology, founded in 1934 by Professor André Dreyfus, who headed it. There began Professor Pavan's academic career. Endowed with great manual skills, with a remarkable intellect, creativity and persistence, he worked from 1941 to 1944 on his doctoral thesis, an important genetic-evolutionary study on the blind catfish of the Iporanga caves, in the state of São Paulo.

Professor Pavan's entrance into the academic world coincided with a period of special importance in the development of Genetics in Brazil. The teaching of Genetics started in Brazil in 1918 at the then named Escola Agrícola

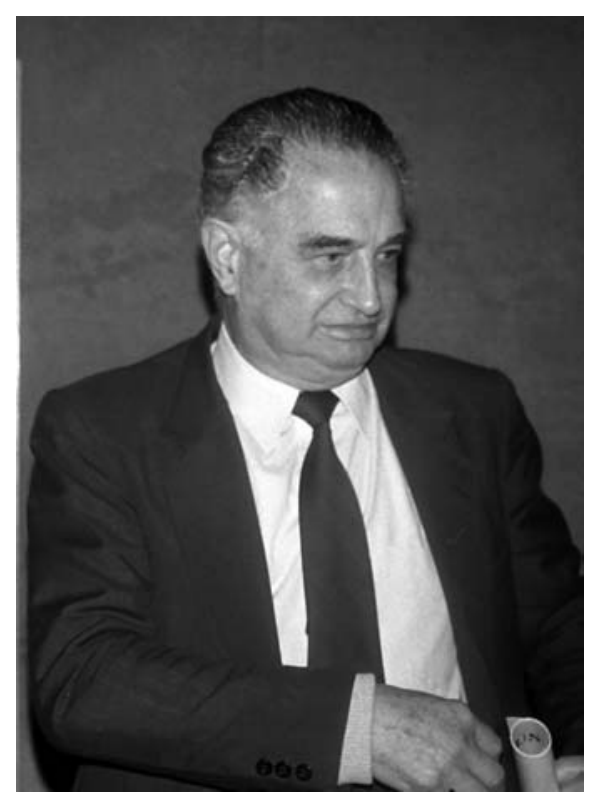

Pavan, July 1993 (Photographed by Carlos R. Vilela. Archives of the Department of Genetics and Evolutionary Biology, IB-USP). de Piracicaba (School of Agriculture of Piracicaba), followed in 1927 by the Faculdade de Medicina (School of Medicine) at USP and in 1933 by the Instituto Agronômico de Campinas (Agronomy Institute of Campinas), but experienced its great impulse when the Chair of General Biology, held by Professor André Dreyfus, was created at the School of Philosophy, Sciences and Humanities at USP in 1934, and the Chair of Cytology and General Genetics, headed by Professor Friedrich Gustav Brieger, at the USP Escola Superior de Agricultura "Luiz de Queiroz" (Higher School of Agriculture Luiz de Queiroz), in Piracicaba in 1936. In 1943, upon an invitation of Professor Dreyfus and sponsored by the Rockefeller Foundation, Professor Theodosius Dobzhansky came to São Paulo for two months to study tropical Drosophila species, which represented the start of the studies on the genetics and evolution of these insects in our country. Pavan and other faculty of the laboratory participated in this work, and thereafter Pavan did his post-doctoral work (1945-46) at Professor Dobzhansky's laboratory at Columbia University, in the US. Then, in 1951, he passed the exam for a Habilitated ("Livre-Docente") Professor at USP with the presentation of his thesis on lethal gene allelism in Drosophila willistoni, and in 1953 he became a Full Professor of the Department of General Biology by presenting his thesis on "Relations between natural Drosophila populations and the environment". In 1952, after the premature passing away of Professor Dreyfus, Pavan took over the Chair of General Biology at the USP School of Philosophy, Sciences and Humanities, which he headed until 1970, when a university reform extinguished the Chairs. Over the following years, he again occupied a director position for several terms as Head of the new Department of Biology, now belonging to the Instituto de Biociências (Institute of Biosciences) at USP, until his retirement in 1978. He then transferred to the Instituto de Biologia, Universidade Estadual de Campinas (Institute of Biology of the State University of Campinas, UNICAMP), where he became Head of the Department of Genetics and Evolution, Director of the Institute of Biology and went into mandatory retirement in 1989.

Pavan accepted an invitation to set up a laboratory at the Biology Division of the Oak Ridge National Laboratories in the US (1964-1965) for studies on gene action and the effects of ionizing radiation, using the insect model he had discovered and with which he was working, Rhynchosciara. At this laboratory, three of his young assistants at USP performed pre-doctoral internships. In 1968, Pavan was hired as a Tenured Full Professor by the University of Texas at Austin (UT), USA, but in 1975 he chose to come back to Brazil. In the meantime he was able to pro- 
vide internships at that University for a number of faculty members of the USP Department of Biology, by means of an agreement with the National Institutes of Health. At all three universities where he worked - USP, UNICAMP and UT - Pavan stood out as an excellent teacher, captivating the students by his knowledge, creativity and also, why not mention it, by his highly polemic and provocative attitude. His only purpose, however, was always to convey scientific knowledge.

Professor Pavan received countless honors on behalf of the relevance of his work at the university and for the development of science. He was a Professor Emeritus of the University of São Paulo (1989) and of the State University of Campinas (1991), he was granted the National Genetics Prize (1963), the Moinho Santista Prize for Biology from the Moinho Santista Foundation (1980), the Alfred Jurzykowski Prize from the National Academy of Medicine (1986) and the Professor Emeritus-Warrior of Education Prize from the Company-School Integration Center (Centro de Integração Empresa-Escola) and the newspaper "O Estado de São Paulo" (2006). He was awarded the Order of Rio Branco by the Ministry of Foreign Affairs and named Officer of the Order of Merit of the Brazilian Armed Forces in 1986. In 1987, he was further awarded the Ordem da Inconfidência (Order of the "Inconfidence") by the State Government of Minas Gerais and the title of Great Officer of the Order of Merit by the Government of Portugal. In 1994, the Brazilian government granted him the Great Cross of the National Order of Scientific Merit. Professor Pavan was a member of the Brazilian Academy of Sciences (1954), of the São Paulo Academy of Medicine (1969), of the Lisbon Academy of Sciences (1969), of the Vatican Pontifical Academy of Sciences (1978), of the Chilean Academy of Sciences (1983) and of the Third-World Academy of Sciences of the Royal Physiographic Society in Lund, Sweden (1984). He was a founding member of the Academy of Sciences of the State of São Paulo, being elected to be its first president. He was a member of the UNESCO Chair "José Reis" in Scientific Divulgation at the USP Escola de Comunicações e Artes (School of Communications and Arts) and of the Brazilian Association for Scientific Divulgation (ABRADIC).

Professor Pavan developed an outstanding activity in a variety of commissions, organizations, scientific societies and agencies for the fostering of research. He was a member of the Brazilian delegation at the UN Scientific Committee on Effects of Atomic Radiation (1956-1965) and of the Inter-American Committee of Science and Technology. Along with other researchers he played a fundamental role in the creation of the Fundação de Amparo à Pesquisa do Estado de São Paulo - FAPESP (The State of São Paulo Re- search Foundation) and was a member of its first Superior Board (1961 to 1963). He again occupied a position at FAPESP as director-president of its Technical-Administrative Board (1981-1984), leading a movement for the consolidation of its budget and for a raise in the percentage of the State budget destined to the Foundation. In the 1970 's, playing his agglutinating role once more, Pavan conceived the Integrated Genetics Program (Programa Integrado de Genética - PIG), turned real by grants from the funding agencies CNPq-Conselho Nacional de Desenvolvimento Científico e Tecnológico (National Council for Scientific and Technological Development) and FINEP Financiadora de Estudos e Projetos (Research and Projects Funding Agency). From 1975 through 1986, Pavan was the coordinator of this program that encompassed 70 Brazilian laboratories, with a huge success. He was president of the Sociedade Brasileira para o Progresso da Ciência - SBPC (Brazilian Society for the Progress of Science) from 1981 to 1986 , where he stood out by his campaigns on behalf of the inclusion of themes about university autonomy and support for Science and Technology in the Constitution of 1988. He further played a major role in the creation of the Ministry of Science and Technology (1985). He left the presidency of the SBPC only to take office as president of the CNPq, from 1986 to 1990, where one of his outstanding actions was the significant increase of scholarships, from 10 thousand to 50 thousand.

Professor Pavan's major achievement, in addition to his actions on behalf of the development of science, is closely and directly related to the development of Animal Genetics in our country. He was the one who carried on and organized the research in Drosophila genetics in Brazil, following the "turmoil created by Dreyfus and Dobzhansky", as Professor Oswaldo Frota-Pessoa described it (excerpt quoted by P. Marques, Revista ADUSP, March 1989). Two publications (A.B. Cunha, Brazilian Journal of Genetics, 12: 683-705, 1989; and C. Pavan \& A.B. Cunha, Genetics and Molecular Biology, 26: 387-395, 2003) make a detailed report of the works performed by $\mathrm{Pa}-$ van and his Brazilian and foreign collaborators from 1943 through 1963. Briefly, we can consider that research on Drosophila underwent three or four phases. In the beginning, the work was directed basically towards collection, cataloguing and description of the Brazilian species of Drosophila, which resulted in a detailed description of the chromosomes, genitalia and body pattern of a great number of tropical species, many of which had special characteristics from the evolutionary point of view, as for instance $D$. willistoni (inversions), D. nebulosa (heterochromatin) and D. polymorpha (morphology). The work progressed with analyses of the correlations among species and environ-

1 "Inconfidence" refers to a political movement against the Portuguese Crown, in the state of Minas Gerais in 1789. 
ment, population size, and geographic distribution of the different species groups. During this phase, there was also a concern about the description of genetic variability and its adaptive value, thus starting the studies on population genetics which resulted in the publication of a great number of papers with unique contributions regarding the evolutionary significance of chromosomal inversions and phenotypic characteristics. With species which were able to adapt to colonization in the laboratory, such as $D$. willistoni, a new phase began, with studies on lethal genes, both originated from natural populations and induced in the laboratory by ionizing radiation. The results of these analyses showed several peculiarities of lethal genes: they are not completely recessive; both natural and synthetic (induced) lethals display a similar behavior in natural populations; selection against these genes is dependent on environmental conditions; lethals are eliminated at a rate that depends on suppressor genes; lethals arise at a higher rate than the mutation rate, due to the arising of synthetic lethals, i.e., lethals produced by recombination of normal chromosomes.

These works on Drosophila had the participation of several Brazilian researchers, who later on either continued these studies or took a path towards genetic studies of other organisms in their own laboratories. Thus, around 1955, there were already teams acting in genetic research in São Paulo, Piracicaba, Campinas, Belo Horizonte, Rio de Janeiro, Curitiba and Porto Alegre. These activities led to the foundation of the Sociedade Brasileira de Genética (Brazilian Society of Genetics) on July $4^{\text {th }}, 1955$, and Professor Pavan was elected its President for the biennial 1958-1960. At that point, there were already "isolated" groups interested in doing research in Human Genetics. Following an agreement with Harry Miller Jr. from the Rockefeller Foundation, Professor Pavan appointed a committee for systematizing and proposing actions for the development of Human Genetics, which allows considering him also as responsible for the development of this important field of research in our country.

Legend has it that in 1951, during one of his trips to collect Drosophila in the banana plantations of Praia Grande in the state of São Paulo coastal area, Pavan kicked the "trunk" of a banana plant that was fallen on the ground and found there a bunch of entangled "worms". Back in the laboratory, he found out that these "worms" were actually larvae of a fly of the genus Rhynchosciara that became the second (and maybe his "dearest" - something Pavan never confessed to) model organism of his studies. This insect displays some biological characteristics which proved special for cytogenetic and molecular analyses: (1) its larvae have larger polytene chromosomes than Drosophila; (2) their polytene chromosomes are "analyzable" in other tissues besides the salivary glands; and (3) the larvae of a given group show an almost synchronous development. Professor Pavan used to say "Analyzing samples of a group on successive days is like watching a movie on the phenom- enon”. In 1952, he and his coworker Marta E. Breuer, after comparing the puffs on the polytene chromosomes from various tissues of Rhynchosciara larvae, published a paper, a classic in the literature (Journal of Heredity 43: 150-157, 1952), showing that the band sequence in the polytene chromosomes of different tissues was similar and, more important yet, that the puff pattern varied with age and among the larval tissues. They proposed that the puffs could be a cytologic manifestation of genes in activity. In an independent work conducted the same year in Germany, W. Beermann reached the same conclusion by analyzing the puffs of the fly Chironomus tentans. After their work of 1952, Pavan and Breuer made a new discovery, a historical landmark in Biology: they showed the accumulation of pycnotic material in some polytene chromosome bands which formed the puffs, while no such thing occurred in the neighboring bands. They demonstrated by specific staining (Feulgen staining) that this material was DNA. Thus, they described for the first time the phenomenon of gene amplification, i.e., production of an extra amount of DNA at specific loci, additional to the normal duplication of the chromosomal strand (Breuer \& Pavan, Chromosoma 7: $371-386,1955)$. Their results were innovative because they were opposed to the dogma in force at the time about DNA constancy and were seen with skepticism. Subsequent studies with another technique (autoradiography), along with

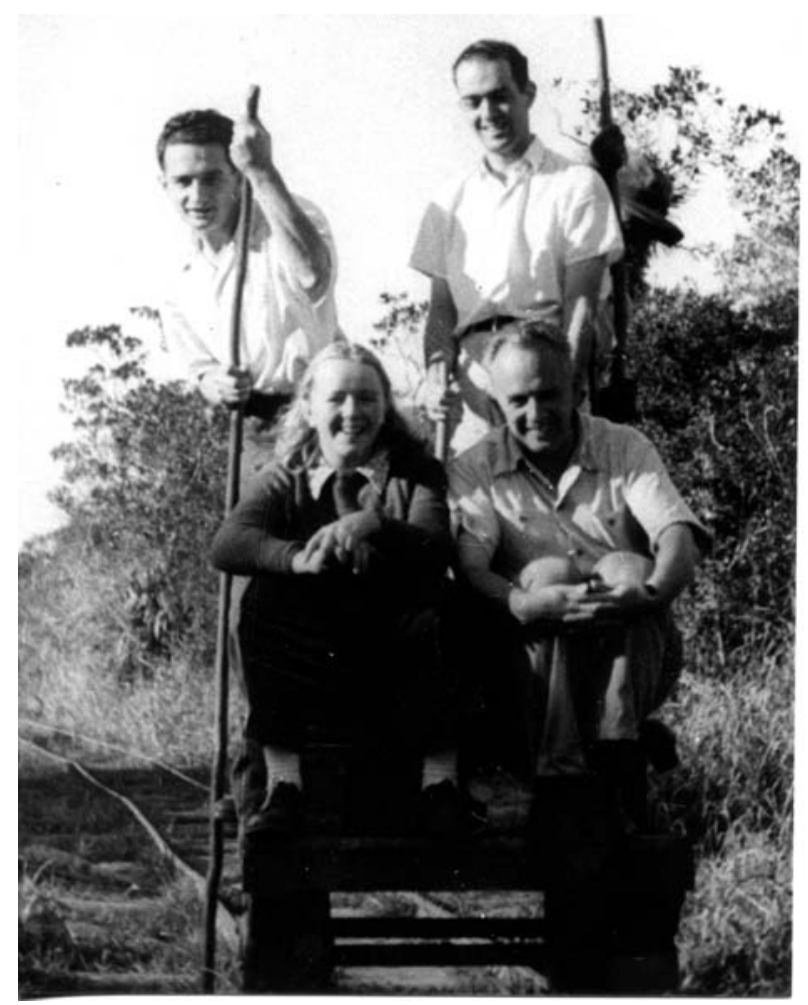

C. Pavan (behind, at left), A. Brito da Cunha (at his side), T Dobzhansky and his daughter Sophie. Photographed by Hans Burla, Vila Atlântica, Praia Grande, State of São Paulo coastal area, 1948/1949. (Archives of the Department of Genetics and Evolutionary Biology, IB-USP). 
independent analyses by cytophotometry performed by other researchers in Rhynchosciara and other related species of sciarid flies, demonstrated that gene amplification actually occurred in these insects. Later on, this phenomenon was also described in other organisms. Brazilian as well as foreign groups proceeded with the studies on DNA puffs in sciarid species and used the new molecular biology techniques to describe the genes located at these chromosomal sites and their products. The discovery made by $\mathrm{Pa}-$ van and Breuer represents one of the most important contributions to Biology made by Brazilian scientists. In 1963, Professor Pavan left his work with Drosophila and turned his attention exclusively towards Rhynchosciara in a variety of analyses, especially on the effects of radiation on chromosomes. And Rhynchosciara had still other novelties in store for the indefatigable Pavan. In 1964, he and his collaborators started a new line of research, on the effects of infections in sciarid cells, describing the reactions of the host cells of these insects when they were infected by microsporidia, gregarines or viruses. A series of studies followed, showing that microsporidia induced an amazing growth of the host cells, with alterations in the cytoplasm structure, and that the polytene chromosomes, which were already huge, became gigantic by undergoing several additional duplication cycles. With infection by gregarines and by the polyhedrosis virus a similar increase in chromosome size was observed, besides other peculiarities. A review of the results obtained until then regarding DNA puffs and infections in sciarid cells was published by Pavan \& Cunha in 1969 (Annual Review of Genetics 3: 425-450).

By the mid-1970's, Professor Pavan suggested some scientists who were developing research in basic Genetics to start using as model organisms insects of economic interest, i.e., insects which cause harm to humans or damage to agriculture and cattle rising. That was how a new phase in his work started, with groups now dedicated to genetic research on the "true" fruit flies which attack an enormous variety of fruits, the flies which cause myiases (blowflies) in humans and animals, and the pasture spithoppers, which cause considerable losses to the production of Poaceae in Brazil. In his last years of life, Professor Pavan turned his attention to another biological problem of great interest: the role of bacteria in nitrogen fixation. In order to conduct his research, he joined the Department of Microbiology at the Instituto de Ciências Biomédicas - USP (Institute of Biomedical Sciences) as a voluntary researcher.

Professor Pavan published over a hundred scientific works and helped forming a contingent of researchers whose number multiplied by advising others, who in turn helped shaping new researchers. He thus leaves behind him a lineage of "scientific children, grandchildren and greatgrandchildren". His death opens a gap in the Brazilian scientific community, but what remains is the certainty of his enormous legacy as a human being, as a man of Science and as the one who was responsible in great part for the development of science, in particular Genetics, in Brazil.

Crodowaldo Pavan was an innovative, creative, provocative man, but above all a fighter. That was him, even recently, in early March, when he was already debilitated by his illness, but would not miss answering an interview as member of the Pontifical Academy of Sciences on the International Conference on Biological Evolution: Facts and Theory, organized by the Vatican's Pontifical Council for Culture, giving his opinion about Science and Religion. He was always a warrior. His words, pronounced when he was interviewed after receiving the "Warrior of Education Trophy", portray his unforgettable way of being: "I consider myself a lucky person, because things happened in my life just as I would have liked it; I had a lot of fun, got whatever I could get and am satisfied with all I did and lived".

André L.P. Perondini João S. Morgante Departamento de Genética e Biologia Evolutiva, Instituto de Biociências, Universidade de São Paulo, São Paulo, SP, Brazil 